\title{
Kinetics of viral shedding provide insights into the epidemiology of viral hemorrhagic septicemia in Pacific herring
}

\author{
Paul Hershberger ${ }^{1, *}$, Jacob Gregg ${ }^{1}$, Courtney Grady ${ }^{1}$, Rachael Collins $^{1}{ }^{\text {, James Winton }}{ }^{2}$ \\ ${ }^{1}$ US Geological Survey, Western Fisheries Research Center, Marrowstone Marine Field Station, 616 Marrowstone Point Road, \\ Nordland, Washington 98358, USA \\ ${ }^{2}$ US Geological Survey, Western Fisheries Research Center, 6505 NE 65th Street, Seattle, Washington 98115, USA
}

\begin{abstract}
Losses from infectious diseases are an important component of natural mortality among marine fish species, but factors controlling the ecology of these diseases and their potential responses to anthropogenic changes are poorly understood. We used viral hemorrhagic septicemia virus (VHSV) and a laboratory stock of Pacific herring Clupea pallasii to investigate the kinetics of viral shedding and its effect on disease transmission and host mortality. Outbreaks of acute disease, accompanied by mortality and viral shedding, were initiated after waterborne exposure of herring to concentrations of VHSV as low as $10^{1}$ plaque-forming units (pfu) $\mathrm{ml}^{-1}$. Shed virus in flow-through tanks was first detected 4 to $5 \mathrm{~d}$ post-exposure, peaked after 6 to $10 \mathrm{~d}$, and was no longer detected after $16 \mathrm{~d}$. Shedding rates, calculated from density, flow and waterborne virus titer reached 1.8 to $5.0 \times 10^{8} \mathrm{pfu}_{\mathrm{fish}}^{-1} \mathrm{~d}^{-1}$. Onset of viral shedding was dose-dependent and preceded initial mortality by 2 d. At 21 d, cumulative mortality in treatment groups ranged from 81 to $100 \%$ and was dependent not on challenge dose, but on the kinetics and level of viral shedding by infected fish in the tank. Possible consequences of the viral shedding and disease kinetics are discussed in the context of epizootic initiation and perpetuation among populations of wild Pacific herring.
\end{abstract}

KEY WORDS: Viral shedding $\cdot \mathrm{VHSV} \cdot$ Pacific herring $\cdot$ Clupea pallasii $\cdot$ Disease ecology

\section{INTRODUCTION}

Widespread in portions of the Northern Hemisphere, viral hemorrhagic septicemia virus (VHSV) is one of the most important pathogens of marine and freshwater fish, causing acute disease (viral hemorrhagic septicemia, VHS) in a broad range of species (Skall et al. 2005). Four major genogroups of VHSV have been identified that generally correlate with geographic range. Isolates of VHSV Genogroup IV have been obtained from both marine and freshwater fishes in North America and Japan. Two subtypes are known. Isolates representing Genogroup IVa cause disease and associated losses in marine and estuarine fishes along the west coast of North America (Meyers \& Winton 1995, Hedrick et al. 2003) and in Japan (Mori et al.
2002), while Genogroup IVb isolates are responsible for emerging disease epizootics, some associated with mass mortalities, in estuarine and freshwater fishes on the east coast and Great Lakes regions of North America (Elsayed et al. 2006, Gagné et al. 2007, Groocock et al. 2007, Lumsden et al. 2007).

Genogroup IVa isolates of VHSV from marine fish in the North Pacific Ocean, hereafter referred to as VHSV, are highly pathogenic for Pacific herring Clupea pallasii Valenciennes, 1847, and large epizootics have occurred repeatedly throughout the eastern North Pacific among free-ranging populations (Meyers \& Winton 1995, Kocan et al. 2001a, Hedrick et al. 2003) and in confined stocks (Kocan et al. 1997, Hershberger et al. 1999, 2001, 2006). Additionally, a leading hypothesis for the collapse and failed recovery of Pacific 
herring populations in Prince William Sound, Alaska, involves excess mortality from disease (Marty et al. 1998, 2003), although the precise role of VHS remains controversial (Elston \& Meyers 2009).

Factors contributing to the onset of VHS epizootics in populations of wild marine fishes are not well understood, but initial infection occurs following direct contact with exogenous waterborne virus (Kocan et al. 2001a). Laboratory studies show that epizootics are readily initiated in naïve stocks of Pacific herring after a $1 \mathrm{~h}$ waterborne exposure to moderate levels $\left(10^{3}\right.$ plaque-forming units [pfu] $\mathrm{ml}^{-1}$ ) or greater of VHSV (Kocan et al. 1997). However, field surveys have detected only low titers of virus ( 5 to $15 \mathrm{pfu} \mathrm{m}^{-1}$ ) in samples of marine water collected in the vicinity of free-ranging schools of herring (Hershberger et al. 1999).

The objectives of this study were to determine the minimum exposure thresholds required to initiate epizootics of VHS in Pacific herring and to quantify the kinetics of viral shedding from infected fish. These empirically deduced infection thresholds and virus shedding rates are discussed in the context of disease initiation and perpetuation in wild marine fishes.

\section{MATERIALS AND METHODS}

Minimum exposure levels required to initiate VHS epizootics in groups of $1+\mathrm{yr}$ old (mean length $=100 \mathrm{~mm}$, $\mathrm{SD}=7.2 \mathrm{~mm}$ ), specific pathogen-free (SPF) Pacific herring (Hershberger et al. 2007) were determined by immersing fish in seawater containing dilutions of a VHSV isolate (99-292) representative of Genogroup IVa. Pacific herring were exposed to $10^{1}, 10^{2}$ or $10^{3} \mathrm{pfu} \mathrm{ml}^{-1}$ for durations of 1 or $24 \mathrm{~h}$ (see Table 1) in triplicate seawater tanks; negative controls consisted of equivalent groups of herring in triplicate tanks where phosphate buffered saline (0 pfu ml ${ }^{-1}$ ) was added. Each replicate $270 \mathrm{l}$ tank contained 27 to 31 SPF herring. Upon initiation of the immersion challenges, seawater supply to each tank was turned off and appropriate dilutions of stock virus or saline (control groups) were added. Supply water was turned back on after the predetermined exposure durations (1 or $24 \mathrm{~h}$ ). Thereafter, seawater supply to each tank was maintained at $3.51 \mathrm{~min}^{-1}$ for the remainder of the study $(21 \mathrm{~d})$. To quantify the concentration of virus in each treatment, water samples were collected from each replicate at the beginning $\left(1 \mathrm{~min}, t_{0}\right)$ and end $\left(t_{1 \mathrm{~h}}\right.$ or $\left.t_{24 \mathrm{~h}}\right)$ of the static virus exposure periods. Additionally, to ensure that challenge virus was washed out after the $1 \mathrm{~h}$ and $24 \mathrm{~h}$ exposures, water samples were collected from each tank after the water flow had been restored for $2 \mathrm{~h}$. Ambient seawater temperature during the initial exposure period was $8.2^{\circ} \mathrm{C}$, and averaged $8.5^{\circ} \mathrm{C}$ (range, 8.1 to $9.5^{\circ} \mathrm{C}$ ) during the experiment.
After exposure, titers of shed VHSV in each treatment were determined by sampling $1 \mathrm{ml}$ of flowing seawater from each replicate at daily intervals. Water samples were stabilized by addition of an equal volume of GIBCO ${ }^{\circledR}$ Minimum Essential Medium supplemented with $40 \%$ fetal bovine serum, $100 \mathrm{IU} \mathrm{ml}^{-1}$ penicillin, $100 \mu \mathrm{g} \mathrm{ml}^{-1}$ streptomycin and $100 \mu \mathrm{g} \mathrm{ml}^{-1}$ gentamycin, and buffered to $\mathrm{pH} 7.8$ with $1 \mathrm{M}$ Tris (MEM-40). Virus titer in the stabilized samples was enumerated by plaque assay using monolayer cultures of epithelioma papulosum cyprini (EPC) cells pretreated with polyethylene glycol (Batts \& Winton 1989). Concentrations of waterborne VHSV in each treatment were reported as the arithmetic means of titers from the 3 replicates and were expressed as pfu $\mathrm{ml}^{-1}$.

Daily virus shedding rates (pfu fish $\mathrm{pd}^{-1}$ ) were calculated as:

$$
\begin{gathered}
\text { Shedding rate }=(\text { waterborne virus titer } \times \\
\text { flow rate }) / \text { fish count, }
\end{gathered}
$$

where waterborne virus titer (pfu $\mathrm{ml}^{-1}$ ) was determined from daily water samples, flow rate was 3.51 $\mathrm{min}^{-1}$, and fish count was the total number stocked into the tank minus the sum of mortalities from all previous days.

Dead and moribund fish were sampled daily and all survivors were euthanized with an overdose of tricaine methanesulfonate (MS-222) and sampled $28 \mathrm{~d}$ postexposure. Kidney and spleen tissues were removed from all sampled fish, pooled by replicate tank and homogenized and serial 10-fold dilutions of the homogenates plated onto EPC cells for plaque assay. Viral tissue titers were calculated from dilution and plaque count and expressed as pfu g $\mathrm{g}^{-1}$ of tissue.

\section{RESULTS}

Waterborne titers of exogenous VHSV in the static exposure tanks were similar at the beginning and end of the $1 \mathrm{~h}$ exposure period, but declined appreciably by the end of the $24 \mathrm{~h}$ exposure period (Table 1). Mean exposure titers in the $10^{1}, 10^{2}$ and $10^{3}$ groups exposed to VHSV for $1 \mathrm{~h}$ were 40,253 and $2693 \mathrm{pfu} \mathrm{ml}^{-1}$ at $t_{0}$ and 47,340 and $3063 \mathrm{pfu} \mathrm{ml}^{-1}$ after $1 \mathrm{~h}$, respectively. Mean exposure titers in the $10^{1}$ and $10^{2}$ groups exposed to VHSV for $24 \mathrm{~h}$ were 27 and $407 \mathrm{pfu} \mathrm{ml}^{-1}$ at $t_{0}$

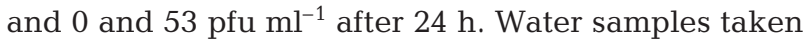
$2 \mathrm{~h}$ after seawater flow was resumed indicated that the challenge virus was rapidly flushed from the tanks. Waterborne virus was not detected in any of the negative control replicates.

Exposures of $1 \mathrm{~h}$ to approximately $10^{2}$ to $10^{3} \mathrm{pfu} \mathrm{ml}^{-1}$ resulted in epizootics in all treatment replicates (Fig. 1A,C), characterized by 95 to $96 \%$ cumulative 
Table 1. Clupea pallasii exposed to VHSV. Titer of waterborne VHSV during the initial exposure period. Numerals in series indicate the waterborne titer (pfu [plaque-forming units] $\mathrm{ml}^{-1}$ ) in each triplicate tank. ${ }^{*}$ replicates where VHS epizootics did not ensue. $t_{3 \mathrm{~h}}$ and $t_{26 \mathrm{~h}}$ samples were collected $2 \mathrm{~h}$ after the water supply was resumed to the 1 and $24 \mathrm{~h}$ treatments, respectively

\begin{tabular}{|c|c|c|c|c|c|}
\hline \multirow{3}{*}{$\begin{array}{l}\text { Time after exposure } \\
\text { (h) }\end{array}$} & \multicolumn{5}{|c|}{ - Exposure treatments } \\
\hline & & $1 \mathrm{~h}$ exposures & 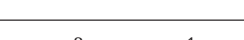 & $24 \mathrm{~h}$ & sures \\
\hline & $10^{1} \mathrm{pfu} \mathrm{ml^{-1 }}$ & $10^{2} \mathrm{pfu} \mathrm{ml^{-1 }}$ & $10^{3} \mathrm{pfu} \mathrm{ml}^{-1}$ & $10^{1} \mathrm{pfu} \mathrm{ml}^{-1}$ & $10^{2}$ pfu ml ${ }^{-1}$ \\
\hline 0 & $40^{*}, 40^{*}, 40^{*}$ & $300,220,240$ & $2620,2040,3420$ & $20,20^{*}, 40^{*}$ & $500,400,320$ \\
\hline 1 & $20^{*}, 80^{*}, 40^{*}$ & $480,380,160$ & $3160,3090,2940$ & $60,0^{*}, 0^{*}$ & $380,280,220$ \\
\hline 3 & $0^{*}, 0^{*}, 0^{*}$ & $40,60,40$ & $1340,1340,1140$ & & \\
\hline 24 & & & & $0,0^{*}, 0^{*}$ & $140,0,20$ \\
\hline 26 & & & & $0,0^{*}, 0^{*}$ & $0,0,0$ \\
\hline
\end{tabular}
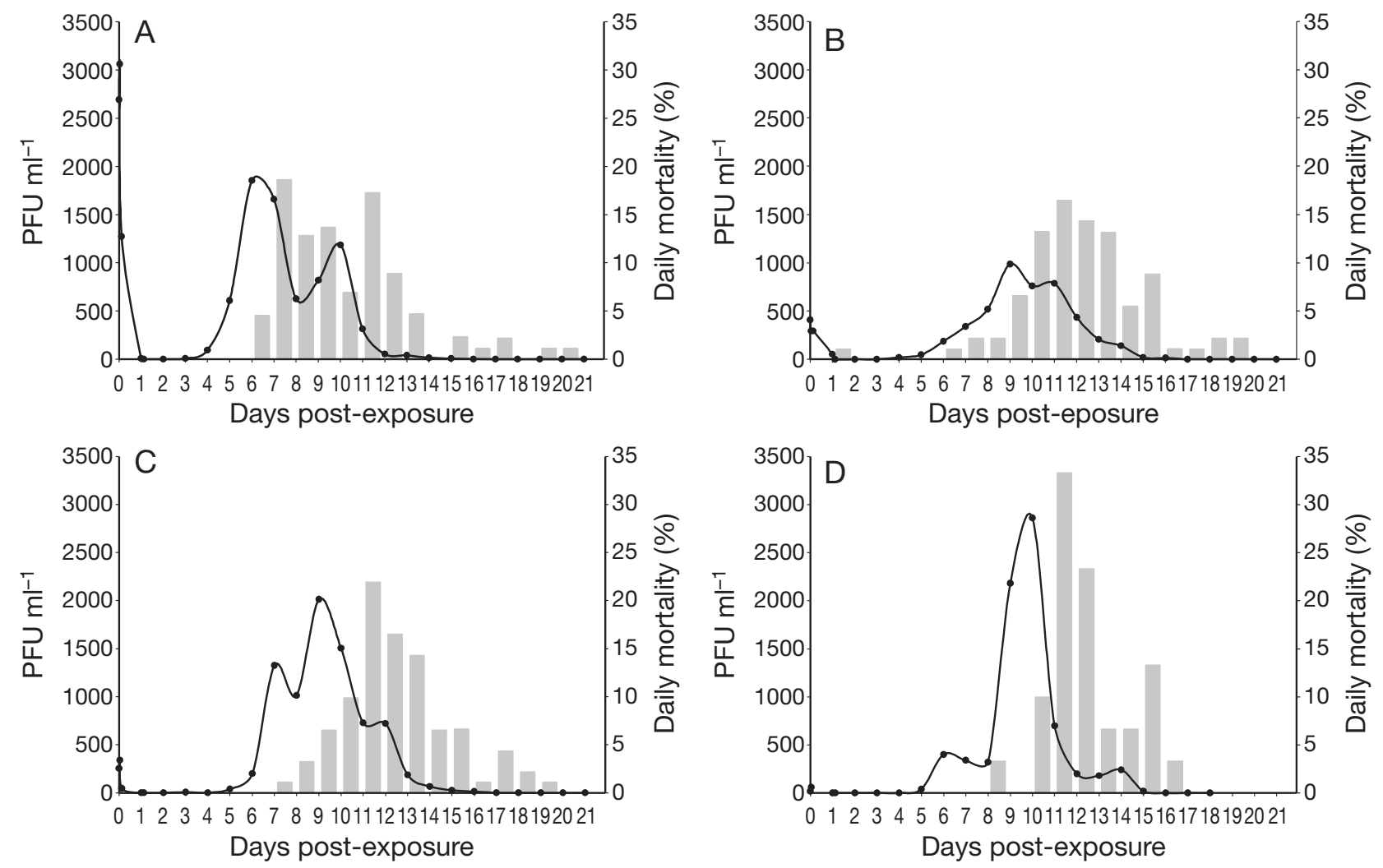

Fig. 1. Clupea pallasii exposed to VHSV. Titer of waterborne VHSV (line) and daily mortality (bars) in tanks of pathogen-free Pacific herring after exposure to virus. (A) Mean titer and daily mortality in triplicate tanks ( $\mathrm{n}=27$ to 30 herring tank $^{-1}$ on Day 0 ) after exposure to 2693 to 3063 plaque-forming units (pfu) $\mathrm{ml}^{-1}$ for $1 \mathrm{~h}$. Cumulative mortality was $95 \%$ when the experiment was terminated at $21 \mathrm{~d}$ after exposure. (B) Mean titer and daily mortality in triplicate tanks ( $\mathrm{n}=30$ to $31 \mathrm{herring}^{\mathrm{tank}} \mathrm{k}^{-1}$ on Day 0$)$ after exposure to 293 to $407 \mathrm{pfu} \mathrm{ml}^{-1}$ for $24 \mathrm{~h}$. Cumulative mortality was $91 \%$ when the experiment was terminated at $21 \mathrm{~d}$ after exposure. (C) Mean titer and daily mortality in triplicate tanks ( $\mathrm{n}=30$ to 31 herring tank $^{-1}$ on Day 0 ) after exposure to 253 to 340 pfu $\mathrm{ml}^{-1}$ for $1 \mathrm{~h}$. Cumulative mortality was $96 \%$ when the experiment was terminated at $21 \mathrm{~d}$ after exposure. (D) Mean titer and daily mortality in a single tank of herring $(\mathrm{n}=30)$ exposed to 23 to $27 \mathrm{pfu} \mathrm{ml}^{-1}$ for $24 \mathrm{~h}$. Of the 3 replicate tanks, a VHS epizootic occurred in only one (shown)

mortality and recovery of VHSV from 51 of 59 tissue pools $(86 \%)$ collected from daily mortalities (median tissue titer $=5.7 \times 10^{5} \mathrm{pfu}^{-1}$ ). Additionally, VHSV was detected in 5 of 5 tissue pools $(100 \%)$ obtained from 6 survivors (median tissue titer $=1.2 \times 10^{4} \mathrm{pfu} \mathrm{ml}^{-1}$ ). However, epizootics did not occur in any replicate group exposed to $10^{1} \mathrm{pfu} \mathrm{ml^{-1 }}$ for $1 \mathrm{~h}$, where cumula- tive mortality was $2 \%$ and VHSV was recovered from only 1 of 2 mortalities and at low titer $\left(1.2 \times 10^{2} \mathrm{pfu} \mathrm{g}^{-1}\right)$; no VHSV was recovered from 3 tissue pools collected from survivors.

Laboratory-induced VHS epizootics occurred after $24 \mathrm{~h}$ exposure of SPF herring to waterborne concentrations of VHSV ranging from $10^{1}$ to $10^{2} \mathrm{pfu} \mathrm{ml}^{-1}$ (Fig. 1). 
later amplified the amount of waterborne virus in the tank by shedding massive quantities virus (as high as $10^{8}$ pfu herring ${ }^{-1} \mathrm{~d}^{-1}$, Table 2), thereby exposing tank cohorts to much higher levels than occurred during the initial exposure level (Fig. 1). This mechanism is supported by the kinetics of the epizootic that occurred after exposure to $10^{1} \mathrm{pfu} \mathrm{m}^{-1}$ for $24 \mathrm{~h}$, when a single fish was probably infected during the initial exposure on Day 0, shed virus into the water on Days 5 to 7 and died on Day 8 (Fig. 1D). Exogenous virus shed from this individual was concentrated in the tank (Fig. 1D) at much higher titers than the initial exposure (Table 1), and the resulting increased infection pressure was sufficient to initiate a full epizootic among the previously uninfected cohorts in the tank. Therefore, the laboratory-based VHS model-system used here is probably sensitive to factors that increase the probability of infection in a single individual, including increasing the number of individuals in the tank, decreasing rate of water exchange, increasing the proportion of highly susceptible individuals or increasing the VHSV exposure titer and duration.

In the natural environment, VHSV infections are found in free-ranging schools of Pacific herring among a very small percentage of individual fish (Marty et al. 1998, Kocan et al. 2001a). These fish actively shed virus because detectable titers of waterborne VHSV can be readily found soon after placing newly captured wild herring into static transport tanks, and VHS epizootics routinely occur following the stress of capture, transfer and confinement of wild cohorts in laboratory aquaria or marine net pens (Hershberger et al. 1999, 2001, 2006, Kocan et al. 2001a). During endemic conditions, free-ranging Pacific herring appear to experience relatively low infection pressures due to their highly migratory behavior and the dilution of virus shed by a small number of individuals in a large water mass. However, infection pressures can become elevated during transient periods of the herring life history when large schools congregate in areas with limited water exchange or in abnormally high densities, such as in predator-corralled aggregations commonly referred to as 'bait balls' or during annual spawning aggregations, where detectable levels of waterborne VHSV have been documented (Hershberger et al. 1999). Similar viral shedding and host mortality kinetics occur with VHSV (Genogroup Ia) and rainbow trout Oncorhynchus mykiss (de Kinkelin et al. 1979, Neukirch \& Glass 1984). As a consequence, VHS is considered the most serious viral disease of farmed rainbow trout in Europe (Smail 1999) where yearly losses from the disease are estimated at 20000 to $30000 \mathrm{t}$ (de Kinkelin \& Bearzotti 1981). In these situations, the combination of high shedding rates by infected individuals, high densities of largely naïve animals and low virus dilution rates can result in increased infection pressures, higher transmission rates, higher infection prevalence and resulting amplification of shed virus. This scenario results in a dramatically increased $\mathrm{R}_{0}$, the ratio of infected individuals that result from a single infected individual in the population (Ostfeld 2009), which can drive the disease beyond a critical tipping point where it transitions from enzootic to epizootic. Once an epizootic is initiated, acute mortality events can result and quickly spread to other species and geographic areas, owing to massive quantities of virus shed from the diseased population. We demonstrate that minimum exposure levels sufficient to initiate this amplification cascade can approach the lower detection threshold of standard virus enumeration techniques (Fig. 1D); however, initial exposure levels required to initiate epizootics in wild populations are probably variable and depend on constantly changing factors associated with population size, herd immunity, behavioral characteristics, fish age, susceptibility, anthropogenic stressors, season, chance or environmental variables such as temperature and salinity.

From a host population perspective, Pacific herring help to mitigate the negative effects of these intermittent outbreaks of acute VHS by developing a solid adaptive immunity after surviving an epizootic. This hypothesis is supported by field studies that showed a greater resistance to VHS among older age cohorts (Hershberger et al. 1999, 2001, Marty et al. 2003) and by laboratory studies demonstrating resistance among herring that survive previous epizootics of VHS (Kocan et al. 1997, 2001a, Hershberger et al. 2007). Therefore, VHS epizootics can be avoided during transient periods of higher infection pressure if significant portions of the population are immune and if adverse environmental or physiological factors do not result in suppression of a protective immune response. In this regard, several of the reported epizootics among Pacific herring and Pacific sardines Sardinops sagax in the NE Pacific Ocean have been associated with stocks of fish that encountered abnormally low water temperatures, which presumably reduced the ability of the fish immune system to resist infection (Hedrick et al. 2003).

An apparent paradox exists when considering the persistence of VHSV in populations of Pacific herring that are so highly susceptible to acute disease. Although initiation of viral shedding 1 to $2 \mathrm{~d}$ before host mortality occurs (Fig. 1) may facilitate continuous passage of VHSV to new hosts in a school, the rapid kinetics of acute disease should quickly exhaust a discrete population of susceptible individuals and eventually result in virus extinction. Therefore, if continuous passage of virus to susceptible members of the population represents the primary mechanism respon- 
sible for VHSV persistence, then viral compensatory mechanisms are necessary, including a broad host range (Skall et al. 2005) and prolonged viral stability in seawater (Hawley \& Garver 2008), ovarian fluid (Kocan et al. 2001b) and/or suspended particulates (Yoshinaka et al. 2000). Additionally, it is likely that VHSV is also maintained in wild populations through sub-acute manifestations of the disease. In the European rainbow trout industry, it has long been recognized that VHS can be present in acute, chronic and nervous manifestations (Smail 1999), and disease kinetics of the acute form are similar to those we described in Pacific herring (Fig. 1). However, a lasting persistent infection can occur in chronic and nervous forms of the disease, whereby virus can be isolated from organs and nervous tissues for extended periods after exposure. For example, viral shedding occurred for more than $30 \mathrm{~d}$ after exposure of rainbow trout to VHSV at normal temperatures (Neukirch \& Glass 1984), and a low titer of VHSV was detected in the brain of a trout held at low temperature for $421 \mathrm{~d}$ (Neukirch 1986). Current studies in our laboratory indicate that analogous sub-acute forms of VHS can also exist in Pacific herring and are characterized by slower onset of mortality, recovery of virus from tissues of persistent carriers and higher viral tissue titers in nervous tissues than in kidney/spleen homogenates (P. Hershberger unpubl. data). These subacute manifestations of VHS in Pacific herring probably also contribute to VHSV persistence in wild Pacific herring populations by replicating and shedding virus without the immediate predisposition of host mortality.

Major gaps continue to exist in our understanding of ecological principles that govern disease initiation processes in wild fish populations, principally because traditional approaches to studying disease ecology consist primarily of epidemiological inferences based on factor analyses from infection and disease surveillances. Although epidemiological correlations are useful for developing hypotheses based on field observations, they are unable to assign causality to factors that predispose wild fish populations to disease. However, development of the empirical disease model described here, based on the availability of colonies of SPF marine fish, represents a major advancement in our scientific approach by providing a means of controlled manipulation to natural host-pathogen-environment relationships. This empirical approach, when used in combination with traditional epidemiological tools, can be expanded to address other timely issues in disease ecology, including the effects of climate change on the frequency of disease epizootics (Harvell et al. 2002, 2009, Marcogliese 2008, Dobson 2009, Lafferty 2009, Ostfeld 2009, Pascual \& Bouma 2009, Randolph 2009).
Acknowledgements. Funding for this study was provided by the Exxon Valdez Oil Spill Trustee Council, Project No. 070819 and the Fisheries and Aquatic Ecosystem Resources Program of the US Geological Survey. The VHSV isolate used was provided by Dr. K. Garver and G. Traxler, Fisheries and Oceans Canada, Pacific Biological Station. Herring eggs for development of SPF herring colonies were kindly provided by K. Stick and A. Lindquist, Washington Department of Fish and Wildlife, USA. The use of trade, firm or corporation names in this publication is for the information and convenience of the reader. Such use does not constitute an official endorsement or approval by the US Department of Interior or the US Geological Survey of any product or service to the exclusion of others that may be suitable.

\section{LITERATURE CITED}

Batts WN, Winton JR (1989) Enhanced detection of infectious hematopoietic necrosis virus and other fish viruses by pretreatment of cell monolayers with polyethylene glycol. J Aquat Anim Health 1:284-290

de Kinkelin P, Bearzotti M (1981) Immunization of rainbow trout against viral hemorrhagic septicemia with a thermoresistant variant of the virus. Dev Biol Stand 49: 431-439

de Kinkelin P, Chilmonczyk S, Dorson M, Le Berre M, Baudouy AM (1979) Some pathogenic facets of rhabdoviral infection of salmonid fish. In: Bachmann PA (ed) Symposia of microbiology: mechanisms of viral pathogenesis and virulence. WHO Collaborating Centre for Collection and Evaluation of Data on Comparative Virology, Munich, p 357-375

Dobson A (2009) Climate variability, global change, immunity, and the dynamics of infectious diseases. Ecology 90: 920-927

Elsayed E, Faisal M, Thomas M, Whelan G, Batts W, Winton J (2006) Isolation of viral hemorrhagic septicemia virus from muskellunge, Esox masquinongy (Mitchill), in Lake St Clair, Michigan, USA, reveals a new sublineage of the North American genotype. J Fish Dis 29:611-619

Elston RA, Meyers TR (2009) Effect of viral hemorrhagic septicemia virus on Pacific herring in Prince William Sound, Alaska, from 1989 to 2005. Dis Aquat Org 83:223-246

> Gagné N, MacKinnon AM, Boston L, Souter B, Cook-Versloot M, Griffiths S, Olivier G (2007) Isolation of viral hemorrhagic septicemia virus from mummichog, stickleback, striped bass and brown trout in eastern Canada. J Fish Dis 30:213-223

Groocock GH, Getchell RG, Wooster GA, Britt KL and others (2007) Detection of viral hemorrhagic septicemia in round gobies in New York State (USA) waters of Lake Ontario and the St. Lawrence River. Dis Aquat Org 76:187-192

Harvell CD, Mitchell CE, Ward JR, Altizer S, Dobson AP, Ostfeld RS, Samuel MD (2002) Climate warming and disease risks for terrestrial and marine biota. Science 296: 2158-2162

Harvell D, Altizer S, Cattadori IM, Harrington L, Weil E (2009) Climate change and wildlife diseases: When does the host matter the most? Ecology 90:912-920

> Hawley LM, Garver KA (2008) Stability of viral hemorrhagic septicemia virus (VHSV) in freshwater and seawater at various temperatures. Dis Aquat Org 82:171-178

> Hedrick RP, Batts WN, Yun S, Traxler GS, Kaufman J, Winton JR (2003) Host and geographic range extensions of the North American strain of viral hemorrhagic septicemia virus. Dis Aquat Org 55:211-220 
Hershberger PK, Kocan RM, Elder NE, Meyers TR, Winton JR (1999) Epizootiology of viral hemorrhagic septicemia virus in Pacific herring from the spawn-on-kelp fishery in Prince William Sound, Alaska, USA. Dis Aquat Org 37:23-31

- Hershberger PK, Kocan RM, Elder NE, Marty GD, Johnson J (2001) Management of Pacific herring spawn-on-kelp fisheries to optimize fish health and product quality. N Am J Fish Manag 21:976-981

> Hershberger P, Hart A, Gregg J, Elder N, Winton J (2006) Dynamics of viral hemorrhagic septicemia, viral erythrocytic necrosis, and ichthyophoniasis in juvenile Pacific herring Clupea pallasi. Dis Aquat Org 70:201-208

> Hershberger PK, Gregg J, Pacheco C, Winton J, Richard J, Traxler G (2007) Larval Pacific herring, Clupea pallasii (Valenciennes), are highly susceptible to viral hemorrhagic septicemia and survivors are partially protected after their metamorphosis to juveniles. J Fish Dis 30: 445-458

Kocan RM, Bradley M, Elder N, Meyers T, Batts W, Winton J (1997) North American strain of viral hemorrhagic septicemia virus is highly pathogenic for laboratory-reared Pacific herring. J Aquat Anim Health 9:279-290

Kocan RM, Hershberger PK, Elder NE, Winton JR (2001a) Epidemiology of viral hemorrhagic septicemia (VHS) among juvenile Pacific herring and Pacific sandlances in Puget Sound, Washington. J Aquat Anim Health 13: $77-85$

Kocan RM, Hershberger PK, Elder NE (2001b) Survival of the North American strain of viral hemorrhagic septicemia virus (VHSV) in filtered seawater and seawater containing ovarian fluid, crude oil, and serum-enriched culture medium. Dis Aquat Org 44:75-78

Lafferty KD (2009) The ecology of climate change and infectious diseases. Ecology 90:888-900

Lumsden JS, Morrison B, Yason C, Russell S and others (2007) Mortality event in freshwater drum Aplodinotus grunniens from Lake Ontario, Canada, associated with viral hemorrhagic septicemia virus, Type IV. Dis Aquat Org 76: 99-111

Marcogliese DJ (2008) The impact of climate change on the

Editorial responsibility: Otto Kinne (Editor-in-Chief),

Oldendorf/Luhe, Germany parasites and infectious diseases of aquatic animals. Rev Sci Tech Off Int Epizoot 27:467-484

- Marty GD, Frieberg EF, Meyers TR, Wilcock J, Farver TB, Hinton DE (1998) Viral hemorrhagic septicemia virus, Ichthyophonus hoferi, and other causes of morbidity in Pacific herring Clupea pallasi spawning in Prince William Sound, Alaska, USA. Dis Aquat Org 32:15-40

- Marty GD, Quinn TJ, Carpenter G, Meyers TR, Willits NH (2003) Role of disease in abundance of a Pacific herring (Clupea pallasi) population. Can J Fish Aquat Sci 60: 1258-1265

> Meyers TR, Winton JR (1995) Viral hemorrhagic septicemia virus in North America. Annu Rev Fish Dis 5:3-24

Mori KI, Iida $H$, Nishizawa $T$, Arimoto $M$, Nakajima $K$, Muroga K (2002) Properties of viral hemorrhagic septicemia virus (VHSV) isolated from Japanese flounder Paralichthys olivaceus. Fish Pathol 37:169-174

Neukirch M (1986) Demonstration of persistent viral haemorrhagic septicaemia (VHS) virus in rainbow trout after experimental waterborne infection. J Vet Med 33:471-476

Neukirch M, Glass B (1984) Some aspects of virus shedding by rainbow trout (Salmo gairdneri Rich.) after waterborne infection with viral haemorrhagic septicaemia (VHS) virus. Zentbl Bakteriol Mikrobiol Hyg A 257:433-438

$>$ Ostfeld RS (2009) Climate change and the distribution and intensity of infectious diseases. Ecology 90:903-905

> Pascual M, Bouma MJ (2009) Do rising temperatures matter? Ecology 90:906-912

> Randolph SE (2009) Perspectives on climate change impacts on infectious diseases. Ecology 90:927-931

Skall HF, Olesen NJ, Mellergaard S (2005) Viral hemorrhagic septicemia virus in marine fish and its implication for fish farming - a review. J Fish Dis 28:509-529

Smail DA (1999) Viral haemorrhagic septicemia. In: Woo PTK, Bruno DW (eds) Fish diseases and disorders, Vol 3: viral, bacterial, and fungal infections. CAB International Publishing, New York, p 123-147

> Yoshinaka T, Yoshimizu M, Ezura Y (2000) Adsorption of infectious hematopoietic necrosis virus (IHNV) with various solids. J Aquat Anim Health 12:64-68

Submitted: June 10, 2009; Accepted: November 16, 2009 Proofs received from author(s): February 3, 2010 